\title{
KLASIFIKASI TINGKAT KEMATANGAN BUAH BERDASARKAN WARNA DAN TEKSTUR MENGGUNAKAN METODE $K$-NEAREST NEIGHBOR DAN NEAREST MEAN CLASSIFIER (NMC)
}

\author{
Irwan Siswanto $^{1}$, Ema Utami ${ }^{2}$, Suwanto Raharjo ${ }^{3}$ \\ Magister Teknik Informatika, Universitas Amikom Yogyakarta ${ }^{1,2,3}$ \\ Email : irwan.siswanto@students.amikom.ac.id ${ }^{1}, \mathrm{ema} . u @$ amikom.ac.id ${ }^{2}$,wa2n@nrar.net ${ }^{3}$
}

\begin{abstract}
ABSTRAK
Buah apel merupakan tanaman yang biasa tumbuh di iklim sub tropis, berdasarkan data yang dirilis oleh direktorat jenderal holtikultura kementrian pertanian tahun 2015, produk pertanian apel memiliki kontribusi yang cukup tinggi di tahun 2014. Hal ini ditunjukan bahwa buah apel di pulau Jawa telah diproduksi sebanyak 242.763 ton dari 249.915 ton produksi di Indonesia. Salah satu jenis apel yaitu apel manalagi, memiliki ciri yang berbeda dari apelapel lainnya yaitu terdapat pada tingkat warna kematangan buah tersebut. dibutuhkan suatu teknologi yang dapat menentukan nilai tingkat akurasi dari pengklasifikasian kematangan buah apel manalagi sehingga memperoleh nilai yang konsisten. Teknologi saat ini memungkinkan untuk melakukan klasifikasi citra digital, Dan berdasarkan beberapa kelas berdasarkan mutu dan perlu dilakukan penelitian ini untuk mengimplementasikan dan menguji akurasi dari metode $K$-Nearest Neighbor (KNN) dan Nearest Mean Classifier (NMC) untuk klasifikasi tingkat kematangan buah apel berdasarkan karakteristik bentuk dan warna buah dengan harapan nilai akurasi metode $N M C$ lebih dari $87 \%$ sehingga dapat membuktikan bahwa metode tersebut lebih unggul daripada metode KNN berdasarkan penelitian sebelumnya. Berdasarkan hasil pengujian diatas dapat diketahui Algoritma K-Nearest Neighbor dapat melakukan klasifikasi tingkat kematangan buah apel manalagi dengan tingkat nilai akurasi paling tinggi adalah dengan menggunakan fitur warna saja dan kombinasi fitur warna dan tekstur dengan masing-masing menggunakan 1-NN yang menghasilkan persentase kebenaran 73 persen. Hasil pengujian Akurasi yang diperoleh secara global menggunakan Nearest mean classifier menghasilkan tingkat akurasi sebanyak 70 persen.
\end{abstract}

Kata Kunci: klasifikasi, apel manalagi, k-nearest neighbor, nearest mean classifier, fitur visual

\section{ABSTRACT}

The apple is a plant commonly grown in sub-tropical climate, based on data released by the Directorate General of horticulture Ministry of Agriculture in 2015, agricultural products apples have a high enough contribution in 2014. This indicated that the apple on Java island has produced as many as 242,763 tons from 249,915 tons of production in Indonesia. One type of apple, Manalagi apple, has a different characteristic from other apples, which is found in the color level of the fruit's maturity. we need a technology that can determine the value of the accuracy of the classification of the more mature apple, more so that it gets a consistent value. Current technology makes it possible to classify digital images, And based on several classes based on quality and this research needs to be done to implement and test the accuracy of the K-Nearest Neighbor (KNN) and Nearest Mean Classifier (NMC) methods for classification of apple maturity levels based on the characteristics of the shape and color of the fruit with the expectation of accuracy NMC method is more than 87\% 
so that it can prove that the method is superior to the KNN method based on previous research. Based on the test results above, it can be seen that the $K$ Nearest Neighbor Algorithm can classify the level of maturity of the apple again with the highest level of accuracy is to use only color features and a combination of color and texture features using 1-NN each which produces a percentage truth 73 percent. Accuracy test results obtained globally using the Nearest mean classifier produce an accuracy rate of 70 percent.

Keywords: classification, manalagi apple, $k$-nearest neighbor,nearest mean classifier, visual features.

\section{PENDAHULUAN}

Buah apel merupakan tanaman yang biasa tumbuh di iklim sub tropis (Soelarso,1997). Berdasarkan data yang dirilis oleh direktorat jenderal holtikultura kementrian pertanian tahun 2015, produk pertanian apel memiliki kontribusi yang cukup tinggi di tahun 2014. Hal ini ditunjukan bahwa buah apel di pulau Jawa telah diproduksi sebanyak 242.763 ton dari 249.915 ton produksi di Indonesia. Maka dapat disimpulkan bahwa buah apel menjadi salah satu produk holtikultura yang paling banyak diminati dan dikonsumsi oleh masyarakat.

Secara umum tahapan dalam proses klasifikasi citra digital yaitu akusisi citra, pra pengolahan citra, ekstrasi ciri/ fitur, pelatihan, pengujian dan pengukuran akurasi. Tahapan mengekstrak ciri atau informasi dalam citra digital sangat mempengaruhi untuk mengenali objek yang ada dalam citra tersebut. Semakin banyak ciri yang diekstrak akan mempengaruhi tingkat akurasi klasifikasi citra. Terdapat bermacam-macam ekstraksi dalam ekstraksi ciri citra yaitu warna dan tekstur. Salah satu jenis apel yaitu apel manalagi, memiliki ciri yang berbeda dari apel-apel lainnya yaitu terdapat pada tingkat warna kematangan buah tersebut. Dimana buah apel manalagi yang masih belum matang memiliki warna hijau dan untuk buah apel manalagi yang sudah matang memiliki warna hijau kekuningan. Hal tersebut tentu akan sedikit menyulitkan untuk membedakan antara buah apel manalagi yang belum matang maupun yang sudah matang apabila tidak terlalu memiliki ilmu mengenai dunia pertanian terutama pada buah apel. Sebab orang awam dirasa akan sulit membedakan. Sehingga akan diperoleh penilaian yang berbeda oleh setiap individu yang menyebabkan tingkat akurasi yang berbeda. Oleh karena itu dibutuhkan suatu teknologi yang dapat menentukan nilai tingkat akurasi dari pengklasifikasian kematangan buah apel manalagi sehingga memperoleh nilai yang konsisten. Teknologi saat ini memungkinkan untuk melakukan klasifikasi citra digital. Penulis merasa perlu melakukan penelitian ini untuk mengimplementasikan dan menguji akurasi dari metode $K$-Nearest Neighbor $(K N N)$ dan Nearest Mean Classifier (NMC) untuk klasifikasi tingkat kematangan buah apel berdasarkan karakteristik tekstur dan warna buah.

\section{LANDASAN TEORI}

2.1 Buah Apel Manalagi

Buah apel merupakan tanaman yang biasa tumbuh di iklim sub tropis (Soelarso,1997). Buah apel manalagi 
memiliki ciri yang berbeda dari apel-apel lainnya yaitu terdapat pada tingkat warna kematangan buah tersebut. Dimana buah apel manalagi yang masih belum matang memiliki warna hijau dan untuk buah apel manalagi yang sudah matang memiliki warna hijau kekuningan. Hal tersebut tentu akan sedikit menyulitkan untuk membedakan antara buah apel manalagi yang belum matang maupun yang sudah matang apabila tidak terlalu memiliki ilmu mengenai dunia pertanian terutama pada buah apel.

\subsection{Ekstrasi Ciri}

Guna mengenali objek dalam citra dibutuhkan parameter-parameter yang bisa mencirikan objek tersebut. Ekstraksi ciri merupakan proses pengambilan ciri atau karakteristik objek yang dapat digunakan sebagai pembeda dari objek-objek lainnya.Karakteristik inilah yang dipakai sebagai parameter untuk menggambarkan sebuah objek.

\section{a. Ekstrasi Ciri Warna}

Ciri warna digunakan apabila objekobjek yang akan dikenali mempunyai warna yang berbeda. Misalnya, untuk membedakan citra buah apel Amerika berwarna merah dengan apel Malang berwarna hijau digunakan ciri warna sebagai parameternya. Parameterparameter warna didapat dengan cara normalisasi setiap komponen warna RGB (Red Green Blue) pada citra menggunakan persamaan 1 dibawah ini : (Andono, dkk., 2017)

$$
\begin{aligned}
& \mathrm{r}=r r+g+b \\
& g=g r+g+b \\
& b=b r+g+b \text {. } \\
& \mathrm{R}=\text { nilai persentasi merah } \\
& \mathrm{G}=\text { nilai persentasi hijau } \\
& \mathrm{B}=\text { nilai persentasi biru }
\end{aligned}
$$

$r=$ jumlah nilai merah

$\mathrm{g}=$ jumlah nilai hijau

$\mathrm{b}=$ jumlah nilai biru

b. Ekstrasi Ciri Tekstur

\section{1) Contras}

Contrast merepresentasikan variasi antar derajat keabuan suatu daerah. Jika terletak jauh dari pusat diagonal utama, maka nilai kontras akan besar. Rumus menghitung kontras ditunjukkan Persamaan 4 (Kusuma, dkk., 2017).

$\operatorname{var}=\sum i, j(i-j) 2 p(i, j)$

\section{2) Correlation}

Nilai korelasi merepresentasikan tingkat abu-abu ketergantungan linier antara piksel pada posisi tertentu terhadap piksel lain. Rumus menghitung korelasi ditunjukkan Persamaan 5 (Kusuma, dkk., 2017).

$C r=\sum i \sum j(i j) p(i, j)-\mu x \mu y \quad \sigma x \sigma y$

\section{3) Energy}

Energy menyatakan tingkat keseragaman piksel-piksel suatu citra. Semakin tinggi nilai Energy, maka semakin seragam teksturnya. Rumus untuk menghitung Energy dapat dilihat pada persamaan 6 (Kusuma, dkk., 2017).

Energy $=\sum i, j P(i, j) 2$

\section{4) Homogeneity}

Homogeneity menyatakan ukuran kedekatan setiap elemen dari cooccurrence matrix. Rumus untuk menghitung Homogeneity dapat dilihat pada persamaan 7 (Kusuma, dkk., 2017).

Homogeneity $\quad=\sum i, j P(i, j)$ $1+|i-j|$.

2.3. Algoritmat K-Nearest Neighbor $(\mathrm{KNN})$

Algoritmat K-Nearest Neighbor (KNN) adalah sebuah metode untuk 
melakukan klasifikasi terhadap objek berdasarkan data pembelajaran yang jaraknya paling dekat dengan objek tersebut. Data pembelajaran diproyeksikan $\mathrm{k}$ ruang berdimensi banyak, di mana masing-masing dimensi merepresentasikan fitur dari data. Ruang ini dibagi menjadi bagian-bagian berdasarkan klasifikasi data pembelajaran. Sebuah titik pada ruang ini ditandai dengan kelas c, jika kelas c adalah klasifikasi yang paling banyak ditemui pada $\mathrm{k}$ buah tetangga terdekat titik tersebut. (Siregar \& Puspabhuana, 2002) Pada fase training, algoritma ini hanya melakukan penyimpanan vector fitur \& klasifikasi data training sample. Pada fase klasifikasi, fitur-fitur yang sama dihitung untuk testing data (klasifkasinya belum diketahui). Nearest Neighbor adalah pendekatan untuk mencari kasus dengan menghitung kedekatan antara kasus baru \& kasus lama yaitu berdasarkan pada pencocokan bobot dari sejumlah fitur yang ada. (Siregar \& Puspabhuana, 2002) Untuk mendefenisikan jarak antara dua titik yaitu titik pada data training ( $\mathrm{x}$ ) \& titik pada data testing (y) maka dipakai rumus Euclidean, seperti yang ditunjukkan pada persamaan (2) :

$\mathrm{D}(\mathrm{x}, \mathrm{y})=\sqrt{ } \Sigma k-1 n(x k-y k) 2$

Dengan $\mathrm{D}$ adalah jarak antara titik pada data training $\mathrm{x} \&$ titik pada testing $\mathrm{y}$ akan diklasifikasi, dimana $\mathrm{x}=\mathrm{x} 1, \mathrm{x} 2, \ldots, \mathrm{xi}$ \& $\mathrm{y}=\mathrm{y} 1, \mathrm{y} 2, \ldots, \mathrm{yi} \& \mathrm{i}$ merepresentasikan nilai atribut serta $\mathrm{n}$ adalah dimensi atribut.

\subsection{Kelebihan K-Nearest Neighbor} $(\mathrm{KNN})$

KNN memiliki beberapa kelebihan yaitu bahwa dia tangguh terhadap training data yang noisy dan efektif apabila data latihnya besar (Siregar \& Puspabhuana, 2002)

\subsection{Citra Warna}

Citra warna adalah citra yang masingmasing piksel mempunyai 3 (tiga) komponen warna yang spesifik, yaitu komponen merah (red), hijau (green) dan biru (blue). Warna setiap piksel ditentukan oleh kombinasi dari intensitas warna merah, hijau dan biru yang disimpan pada bidang warna di lokasi piksel. Format file grafis menyimpan citra warna sebagai citra 24-bit, yang berasal dari komponen merah, hijau dan biru masing-masing 8 bit. Hal ini menyebabkan citra warna mempunyai 24 juta kemungkinan warna (Hermawati, 2013).

\subsection{Nearest mean Classifier Nearest classifier (NMC)}

Adalah sebuah teknik untuk melakukan klasifikasi (Bhavsar 2017). NMC sebagai sebuah pemilah menggunakan kemiripan antar pola untuk melakukan klasifikasi. Untuk setiap kelas, NMC menghitung rata-rata kelas (centroid) dari sampel data. NMC telah berhasil diterapkan pada masalah klasifikasi dan menunjukkan hasil yang baik. Nearest mean classifier merupakan pemilah linier sederhana untuk mengklasifikasikan sebuah objek yang tidak diketahui ke dalam suatu kelas terdekat. Metode ini disebut juga minimum euclidean distance classifier. Metode ini mudah dimengerti dan mudah diimplementasikan karena tidak membuat asumsi tentang distribusi data dalam ruang fitur. Setiap kelas (cluster) diwakili oleh rata rata vektor fitur objek yang sekelas berdasarkan data sampel. Rata-rata vektor fitur kelas (class mean) menjadi titik pusat kelas atau istilah lainnya adalah centroid. Selanjutnya klasifikasi didasarkan atas jarak terdekat vektor fitur objek dengan 
vektor fitur class mean. Ilustrasi pada gambar berikut ini menunjukan dua buah kelas(cluster) yang di wakili oleh class mean/ centroid.

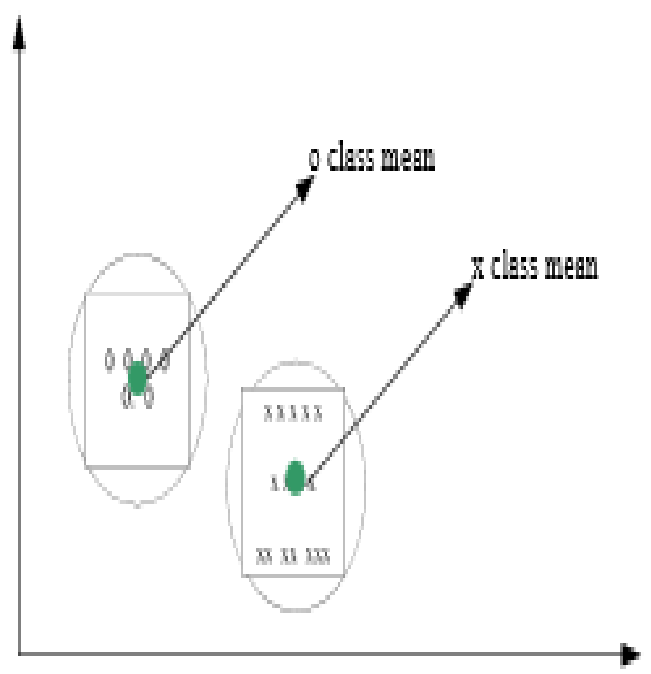

Gambar 1. class mean/ centroid

Class mean pada masing-masing kelas dihitung berdasarkan nilai rata-rata fitur objek yang berada pada kelas yang sama. Aturan klasifikasi pada metode ini dapat dijelaskan sebagai berikut: jika diberikan dua buah kelas w1 dan w2 dan himpunan objek dinyatakan dalam himpunan vektor sebagai $\{x 1, \ldots, x n\}$, jika $x(i)$ adalah mean kelas wi maka untuk objek baru $\mathrm{z}$ diklasifikasikan kedalam kelas wi jika dan hanya jika jarak euclidean D2(z, x (1)) < D2( $z, x$ (2)). Algoritma NMC adalah sebagai berikut:

1. Tentukan class mean untuk setiap kelas.

2. Untuk setiap objek yang akan diklasifikasikan, hitung jaraknya (norma vektor) ke setiap class mean yang ada menggunakan jarak euclidean.

3. Objek diklasifikasikan ke kelas yang jarak objek dengan class mean adalah terdekat (minimum).

\section{METODE PENELITIAN}

3.1. Jenis, Sifat dan Pendekatan

Penelitian

a. Jenis Penelitian

Jenis penelitian ini adalah eksperimen. Eksperimen akan dilakukan dengan menerapkan serangkaian tindakan dimulai dengan melakukan ekstraksi ciriciri data training yaitu nilai tepi dengan menggunakan metode Canny Detector dan nilai RGB, kemudian akan dilakukan pengujian dengan cara melakukan input data citra baru untuk menguji apakah sistem bisa mendeteksi jenis citra baru tersebut.

\section{b. Sifat Penelitian}

Sifat penelitian ini adalah Kausal yaitu untuk memperoleh informasi dari hubungan fitur visual dan jumlah $\mathrm{K}$ yang digunakan dengan tingkat akurasi dalam melakukan klasifikasi jenis rempahrempah menggunakan algoritma K-Nearest Neighbor.

\section{c. Pendekatan Penelitian}

Pendekatan penelitian ini adalah pendekatan Kuantitatif dimana pada penelitian ini melakukan klasifikasi terhadap jenis rempah-rempah yang diambil citranya dan kemudian di ekstrak nilai warna yang terdiri dari nilai red, green, dan blue, kemudian nilai tekstur yang terdiri dari contrast, correlation, energy dan homogeneity, dan terakhir nilai bentuk yang terdiri dari Eccentricity dan Metric.

3.2. Metode Pengumpulan Data

Metode pengumpulan data dapat dibagi berdasarkan jenis data yang dikumpulkan dalam penelitian ini yaitu :

\subsection{Data Premier \\ Data utama pada penelitian ini} adalah menggunakan dataset dari internet yang telah dikelompokan berdasarkan 
kategori-kategori tertentu sehingga dapat menjadi sebuah basis pengetahuan sistem ketika melakukan proses ekstraksi dan klasifikasi.

\subsection{Data Skunder}

Data pendukung pada penelitian ini diperoleh dari data yang di peroleh sacara langsung oleh buah apel manalagi yang di ambil citranya kemudai di ekstrak menjadi nilai.

3.3. Metode analisis Data

Metode analisa data yang digunakan dalam penelitian ini menggunakan metode analisis kuantitatif terhadap hasil akurasi dari klasifikasi tingkat kematangan buah Apel.

\subsection{Alur Penelitian}

Alur penelitian yang akan dilakukan yaitu sebagai berikut :

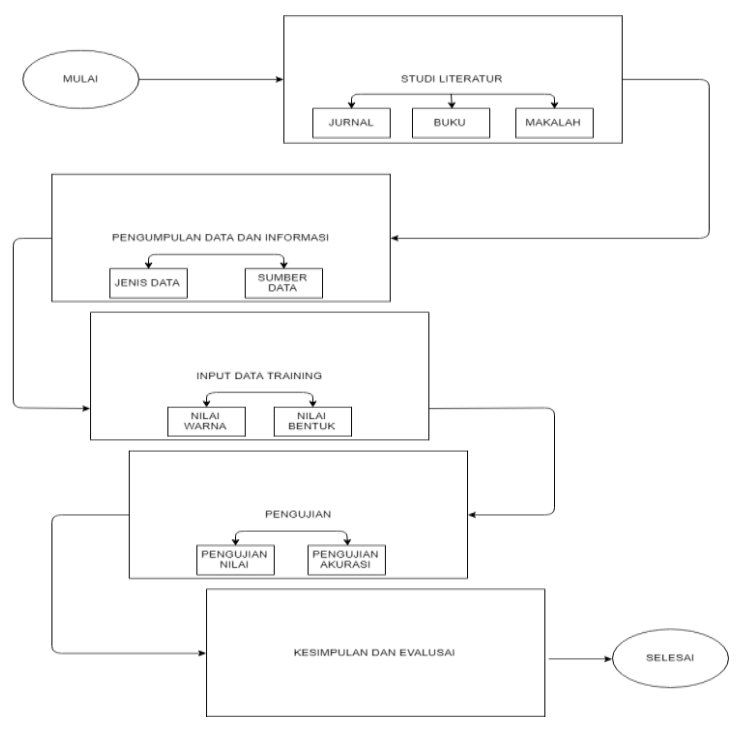

Gambar. 2 Alur Metodologi Penelitian

\section{HASIL DAN PEMBAHASAN}

Pengujian dilakukan dengan menggunakan Aplikasi WEKA Versi 3.9.3, WEKA merupakan aplikasi yang dapat digunakan untuk melakukan analisis data mining, berikut ini gambar 4.8 merupakan contoh tampilan dari WEKA

\subsection{Pengujian Menggunakan K-Nearst Neigbhor \\ Untuk mengetahui nilai dari akurasi} klasifikasi buah apel berdasarkan warna dan tekstur menggunakan algoritma K-Nearest Neighbor maka dilakukan 3 skenario pengujian, seluruh skenario pengujian menggunakan Metode 10-Fold Cross Validation dengan jumlah 100 instances, setiap skenario pengujian dilakukan $3 \mathrm{kali}$, yang pertama dengan menggunakan $\mathrm{K}=1$, yang kedua menggunakan $\mathrm{K}=3$, dan yang ketiga menggunakan $\mathrm{K}=5$ setiap skenario pengujian menggunakan fitur visual yang berbeda-beda, berikut ini adalah hasil pengujian dari tiga skenario pengujian :

a) Pengujian Skenario 1

Pengujian senario 1 adalah pengujian yang dilakukan dengan menggunakan fitur warna. Pengujian ini bertujuan untuk mengetahui berapa nilai akurasi jika hanya menggunakan fitur warna dan tekstur.

1) Pengujian Skenario 1 Dengan 1-NN

Berikut ini gambar 3 hasil pengujian dengan menggunakan fitur warna dan tekstur dengan nilai $\mathrm{K}=1$ :

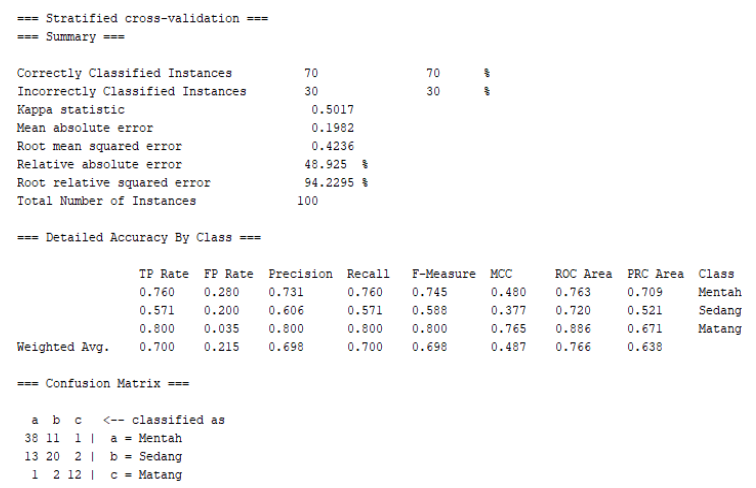

Gambar 3. Hasil Pengujian Skenario 1

Dengan 1-NN

2) Pengujian Skenario 1 Dengan 3-NN 
Berikut ini gambar 4 hasil pengujian dengan menggunakan fitur warna dan tekstur dengan nilai $\mathrm{K}=3$ :

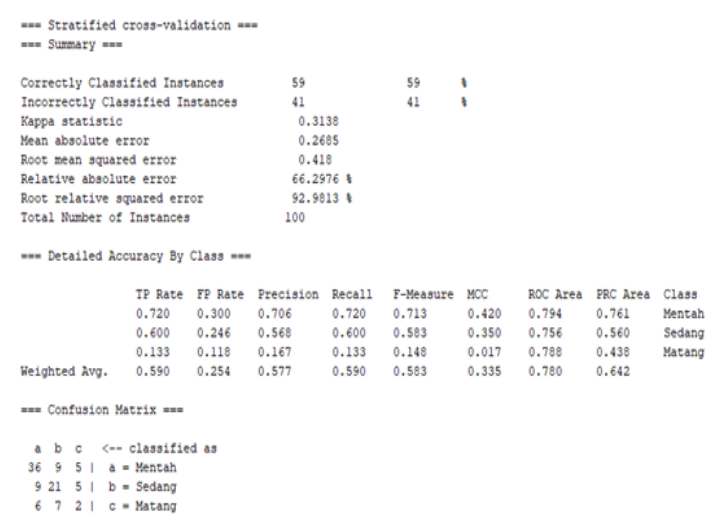

Gambar 4. Hasil Pengujian Skenario 1 Dengan 5-NN

3) Pengujian Skenario 1 Dengan 5-NN Berikut ini gambar 5 hasil pengujian dengan menggunakan fitur warna dan tekstur dengan nilai $\mathrm{K}=5$ :

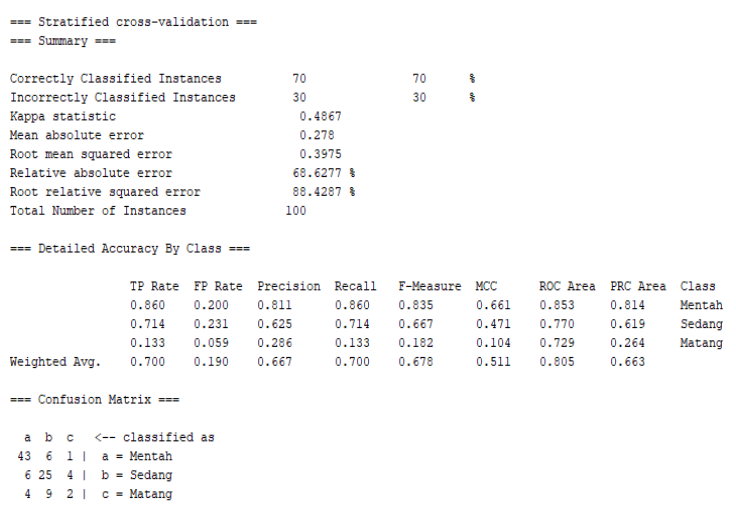

Gambar 5. Hasil Pengujian Skenario 1 Dengan 5-NN

b) Pengujian Skenario 2 Pengujian senario 2 adalah pengujian yang dilakukan dengan menggunakan fitur warna. Pengujian ini bertujuan untuk mengetahui berapa nilai akurasi jika hanya menggunakan fitur warna saja.

1) Pengujian Skenario 2 Dengan 1-NN
Berikut ini gambar 6 hasil pengujian dengan menggunakan fitur warna dengan nilai $\mathrm{K}=1$ :

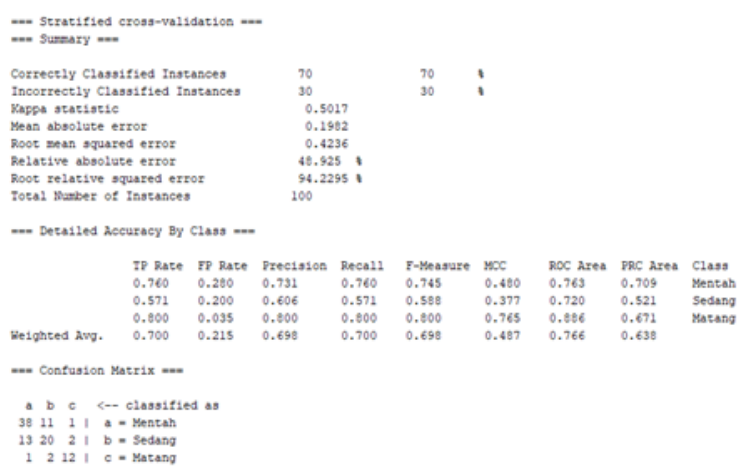

Gambar 6. Hasil Pengujian Skenario 2 Dengan 1-NN

2) Pengujian Skenario 2 Dengan 3-NN

Berikut ini gambar 7 hasil pengujian dengan menggunakan fitur warna dengan nilai $\mathrm{K}=3$ :

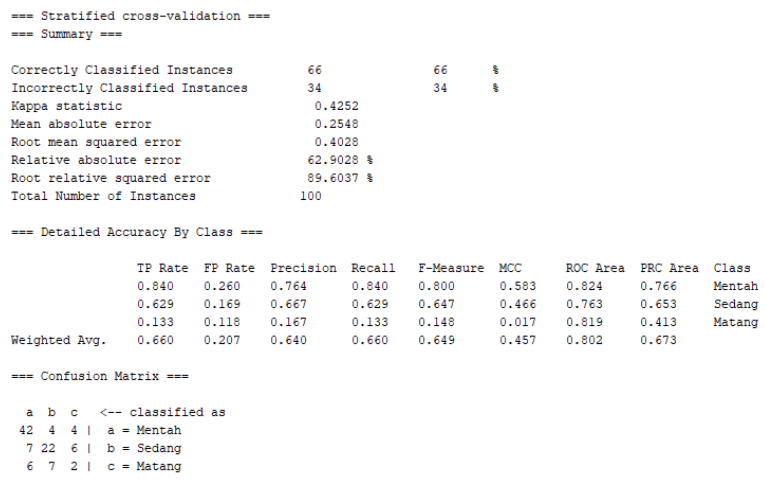

Gambar 7. Hasil Pengujian Skenario 2 Dengan 3-NN

3) Pengujian Skenario 2 Dengan 5-NN

Berikut ini gambar 8 hasil pengujian dengan menggunakan fitur warna dengan nilai $\mathrm{K}=5$ : 


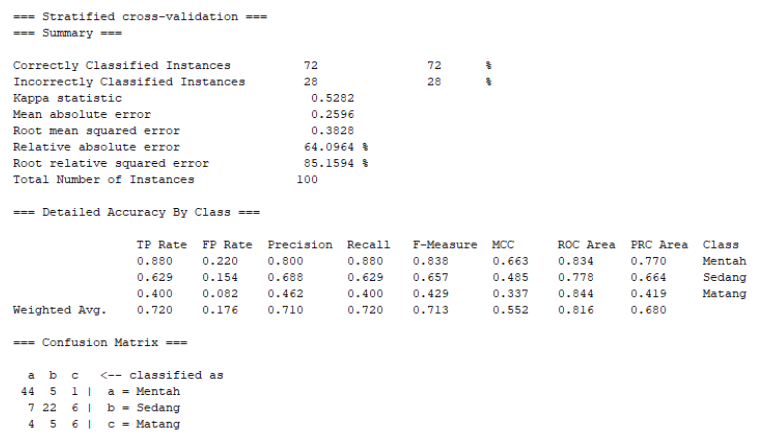

Gambar 8. Hasil Pengujian Skenario 2 Dengan 3-NN

c) Pengujian Skenario 3

Pengujian senario 3 adalah pengujian yang dilakukan dengan menggunakan fitur tekstur. Pengujian ini bertujuan untuk mengetahui berapa nilai akurasi jika hanya menggunakan fitur tekstur saja.

1) Pengujian Skenario 3 Dengan 1-NN

Berikut ini gambar 9 hasil pengujian dengan menggunakan fitur tekstur dengan nilai $\mathrm{K}=1$ :

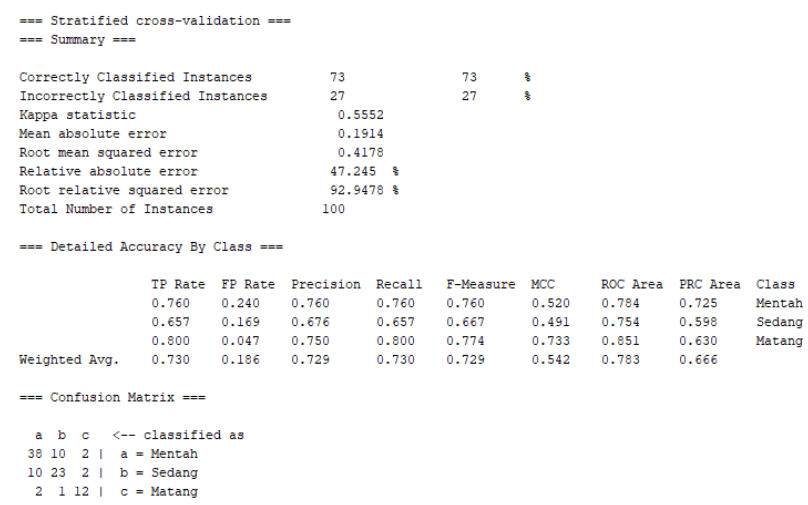

Gambar 9. Hasil Pengujian Skenario 3 Dengan 1-NN

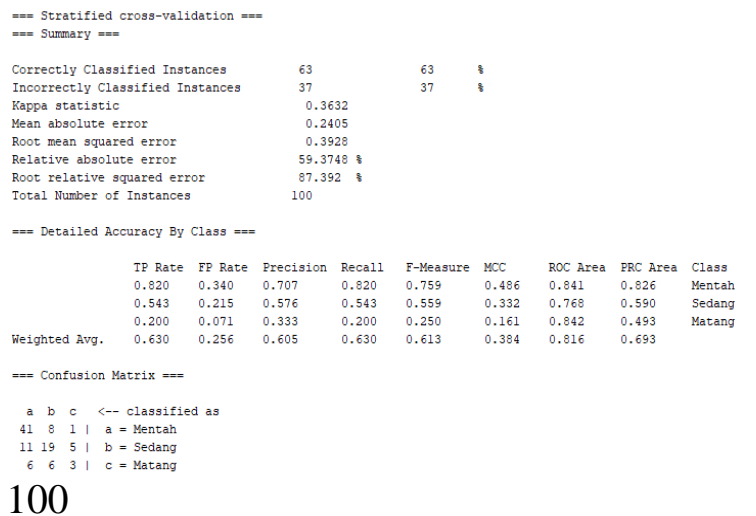

2) Pengujian Skenario 3 Dengan 3-NN

Berikut ini gambar 10 hasil pengujian dengan menggunakan fitur tekstur dengan nilai $\mathrm{K}=3$ :

\section{Gambar 10. Hasil Pengujian Skenario 3 Dengan 3-NN}

3) Pengujian Skenario 3 Dengan 5-NN

Berikut ini gambar 11 hasil pengujian dengan menggunakan fitur tekstur dengan nilai $\mathrm{K}=5$ :

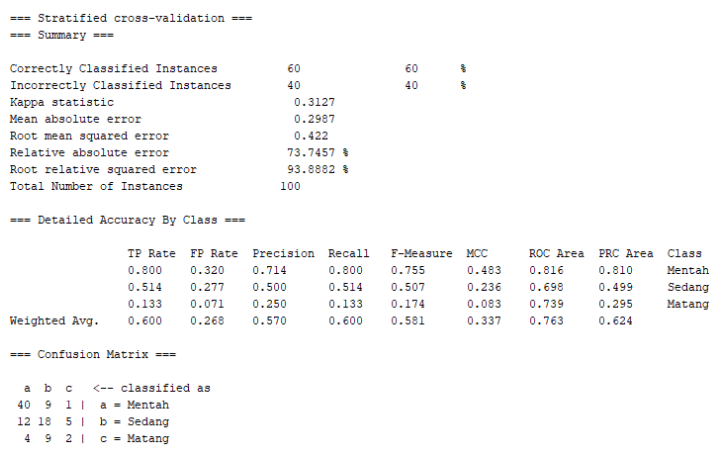

Gambar 11. Hasil Pengujian Skenario 3 Dengan 5-NN

Untuk melihat perbandingan hasil dari 9 skenario pengujian berikut ini disajikan dalam bentuk diagram yang ditunjukkan pada gambar 12

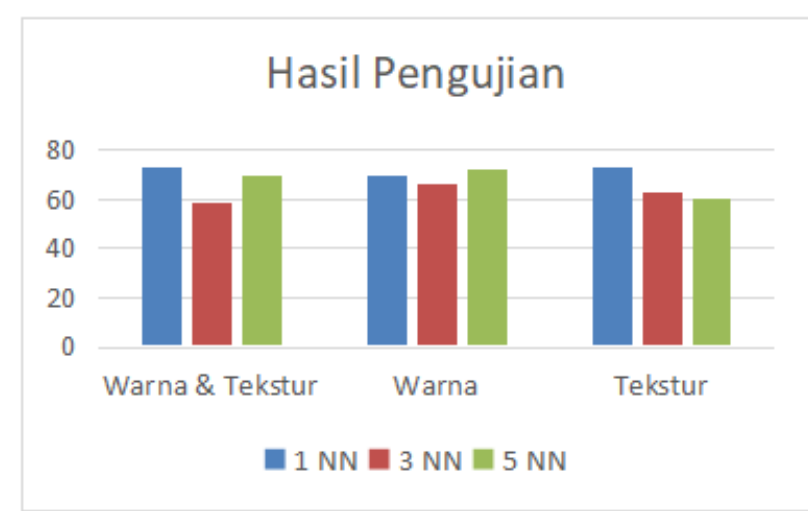

Gambar 12. Persentase Hasil Pengujian

Nilai akurasi paling tinggi adalah dengan menggunakan fitur warna saja dan kombinasi fitur warna dan tekstur dengan 
masing-masing menggunakan 1-NN yang menghasilkan persentase kebenaran 73 persen

\subsection{Pengujian menggunakan Nearest neam classified}

Hasil pengujian Akurasi yang diperoleh secara global menggunakan nmc menghasilkan tingkat akurasi sebanyak 70 persen dapat di lihat pada Gambar Gambar 13. Di bawah ini

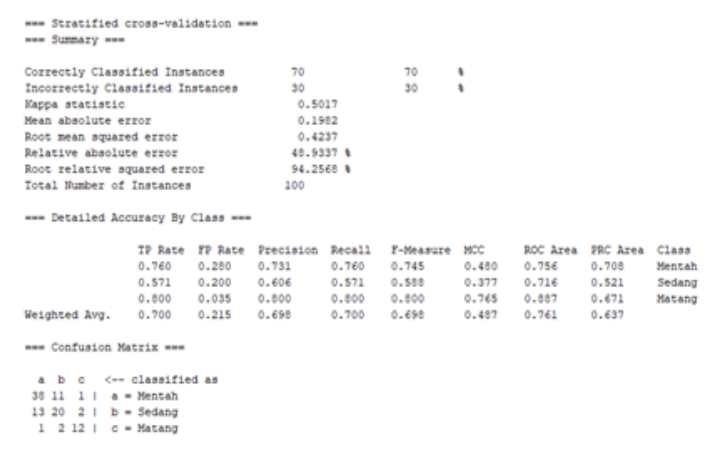

Gambar 13. Hasil pengujian menggunakan nearest mean classifier

\section{SIMPULAN DAN SARAN}

Berdasarkan penelitian yang telah dilakukan maka didapat beberapa kesimpulan sebagai berikut :

a. Berdasarkan hasil pengujian diatas dapat diketahui Algoritma K-Nearest Neighbor dapat melakukan klasifikasi tingkat kematangan buah apel manalagi dengan tingkat nilai akurasi paling tinggi adalah dengan menggunakan fitur warna saja dan kombinasi fitur warna dan tekstur dengan masingmasing menggunakan 1-NN yang menghasilkan persentase kebenaran 73 persen.

b. Hasil pengujian Akurasi yang diperoleh secara global menggunakan Nearest mean classifier menghasilkan tingkat akurasi sebanyak 70 persen c. Kedua algoritma yang di gunakan dalam penelitian ini dapat melakukan klasifikasi menghasilkan presentasi akurasi tidak lebih dari 70 persen.

\section{DAFTAR PUSTAKA}

Abdullah, Usman, M. Efendi,Sistem Klasifikasi Kualitas Kopra Berdasarkan Warna Dan Tekstur Menggunakan Metode Nearest Mean Classifier (NMC) Jurnal Teknologi Informasi dan Ilmu Komputer (JTIIK), 2017

Andono, P. N., Sutojo, T., \& Muljono. (2017). Pengolahan Citra Digital. Yogyakarta: Andi.

Elvia Budianita, Jasril, danLestari Handayani. Implementasi Pengolahan Citra dan Klasifikasi K-Nearest Neighbour Untuk Membangun Aplikasi Pembeda Daging Sapi dan BabiJurnal Sains, Teknologi dan Industri, Vol. 12, No. 2, Juni 2015

Fuzy Yustika Manik, Kana Saputra Saragih,Klasifikasi Belimbing Menggunakan Naïve Bayes Berdasarkan Fitur Warna RGB IJCCS 2017

Hakim, L. (2015). Rempah \& Herba. Yogyakarta: Diandra Creative.

Hambali, E., Fatmawati, \& Permanik, R. (2005). Membuat Aneka Bumbu Instan Kering. Jakarta: Penebar Swadaya

Putra, D. (2010). Pengolahan Citra Digital. Yogyakarta: Andi.

Ratih Kartika Dewi dan Nanik Suciati.Klasifikasi Tanaman berdasarkan Fitur Bentuk dan Tekstur pada Daun menggunakan Decision TreeJurnal Cybermatika | Vol. 3 No. 2 | Desember 2015

Selvia Ferdiana Kusuma, Ratri Enggar Pawening, dan Rohman Dijaya.Otomatisasi klasifikasi 
kematangan buah mengkudu berdasarkan warna dan tekstur.Jurnal Ilmiah Teknologi Sistem Informasi, Januari 2017, Volume 3, Nomor 1
Yanuar Putu Wiharja Agus Harjoko( 2014). Pemrosesan Citra Digital untuk Klasifikasi Mutu Buah Pisang Menggunakan Jaringan Saraf Tiruan 